\title{
Managing Brand Equity among Langkawi’s (SMEs)
}

\section{Independent Hoteliers}

\author{
Maznah Wan Omar (Corresponding author) \\ Faculty of Business Management, Universiti Teknologi MARA \\ Peti Surat 187, 08400 Merbok, Kedah, Malaysia \\ Tel: 60-4-4562-277Ｅ-mail: maznah199@kedah.uitm.edu.my \\ Mohd Noor Mohd Ali \\ Faculty of Applied Science, Universiti Teknologi MARA \\ UiTM P.Pinang, 13500 Permatang Pauh, P.Pinang, Malaysia \\ Tel: 60-4-3823-408 E-mail: mohdnoorma@ppinang.uitm.edu.my
}

\begin{abstract}
In Malaysia the brand management studies among independent hoteliers whose operations are on a small scale basis and are categorized as a small to medium-sized enterprises (SMEs) is in its infancy stage. Although considerable literature has been published about brand management, many theories and cases are based only on multinationals. This paper aims to examine the effectiveness of advertising in the management of hotel branding among independent hoteliers, whereby the focus of the study is among the independent hoteliers in Langkawi.
\end{abstract}

Keywords: Brand management, Hotel branding, Independent hoteliers

\section{Introduction}

Globally, the hotel groups are working hard to build strong brands for more sophisticated and demanding customers, there is increasing pressure on small and medium-sized independent hotels to be able to continue to perform well or even to survive. The former Malaysian Minister of Tourism, Datuk Dr Leo Michael Toyad (Dass, 2005) reiterated that Malaysia has lots to offer to the world, not just tourism but also business facilities, an environment which is politically stable with a stable economy and strong infrastructure, facilities, transport system, including ports and airports. But his statement was not enough to help hoteliers in Malaysia. Studies have shown that owners of smaller independent firms highly value management autonomy (Beaver and Prince, 2004). Based on this assumption, hoteliers which are small and medium-sized enterprises (SMEs) most of the time would like to remain active in the management of their property thus neglecting managing brand of their own.

Reviewing the articles on SMEs, practically nothing has been published about "brand management in Malaysian SME hotels". Until now, it was the marketing function of SMEs that was heavily research. As a result of which brand management received scarcely any attention.

\section{Problem Statement}

The uniqueness of hotels offered by SMEs operators is that, they offer personalization and unique lodging experience geared towards the local culture. These offers will obviously benefits tourists to stay at such hotels (Holverson \& Revaz, 2006; Main, 2001). Other competitive advantage to owning and operating SME hotels, according to Main, is the flexibility that this type of hotel could offer as compared to rigid standardized hotel brands, which allows customization and therefore, the ability to attract niche markets.

Langkawi's independent hotel industry is one of the promising industries in Malaysia, as such it is essential that the key strategies be aligned to meet the economic agenda of Malaysia (Malaysian Ministry of Finance, 2005). Among the competitive advantage that exists in langkawi's independent hoteliers are its tangible and intangible resources, which are scarce, inimitable and non-substitute resources that will allow SME hotels in Langkawi to achieve its competitive advantage as compared to the multi-national hotels.

Unfortunately, Langkawi's independent hotels, and especially SME hotels as a sector, suffer from inherent weaknesses. Much of the problem was issues related to brand management which contributed to misrepresentation in emerging market place. Nonetheless, Langkawi's SME independent hoteliers are dominated 
by family businesses; there may be limited development due to non-economic motives, limited marketing, and issues of quality assurance, pricing policies, cost control and a lack of financial resources (Holverson \& Revaz, 2006; Morrison, 1998). As noted by Morrison, the problematic areas in concern are: under-utilized assets, declining profit margins and higher sensitivity to occupancy and seasonal fluctuations than larger hotels. Buhalis and Main identified the principle disadvantages of SME hotels as: "their lack of capital; deficient economies of scale and under-utilized economies of scope; peripheral; insufficient management and marketing skills and expertise; inadequate bargaining power within the distribution channel; and finally lack of representation in the emerging electronic marketing place" (Buhalis \& Main, 1997, p. 276).

Marketing is seen as a troublesome and problematic undertaking for Langkawi's independent SME hoteliers. But such problems do not appear without reasons. Hill's (2001) study of key factors for effective marketing, confirms that the SME's vigorous sales orientation largely determines the character of their marketing. As a result, promotion is pushed to sidelines and the building of a strong brand becomes even more difficult.

A study by Cohen and Stretch (1989) revealed that the most commonly cited problems from the owners of small companies were marketing problems. This is similar to the findings by Kraft and Goodell (1989), who concluded that of the problems most commonly cited by small business, 75 percent were marketing-related. Additionally, Huang and Brown (1999) provided further confirmation with a study of 973 small businesses in Western Australia where related to brand management issues.

\section{Definition of SME}

Definitions of SME hotels vary somewhat worldwide (Holverson \& Revaz, 2006). According to the WTO a SME hotel is a property with less than 50 rooms which employs less than ten persons and it is oftentimes situated in peripheral locations (Main, 2001). Morrison (1988, p. 191) defines a small hotel as a business which is:

“...financed by one individual or small group, directly managed by its owner(s) in a personalized manner and not through the medium of a formalized management structure".

\subsection{Definition of SMEs in Malaysia}

SMEs in Malaysia were defined for wider coverage and applicability. The definitions of SMEs were based on two criteria, namely: 1) Number of employees; or 2) Annual sales turnover. Thus, an enterprise will be classified as an SME if it meets either the specified number of employees or annual sales turnover definition. A small enterprise in service is an enterprise with full-time employees of between 5 and 19 or with annual sales turnover of between RM200, 000 and less than RM1million. Additionally, a medium enterprise in services is an enterprise with full-time employees of between 20 and 50 or with annual sales turnover of between RM1 million and RM5 million (Bank Negara Malaysia, 2005).

\section{Literature Review}

Brand management is an area of increasing importance to marketers today, particularly as organizations attempts to communicate the ever complex and intangible messages as part of brand management strategies (Davis, 2000; Goodchild \& Callow, 2001). One of the many interesting questions facing today's brand managers concerns how to develop a better understanding of the appropriate relationship between constructs such as brand equity and customer loyalty, particularly in relation to the myriad of known antecedents to customer loyalty in the marketing literature (Taylor et al., 2004). In this study we assess the relative importance of many of the known antecedents to customer loyalty, including brand equity.

By having a strong brand, companies not only could facilitate the differentiation of their offer from the competitors, with branding, SMEs company's are able to create customer confidence and loyalty in their performance, exert greater control over promotion and distribution of the brand, as well as commanding a premium price over the competitors; all while impacting the valuation of the business (Holverson \& Revaz, 2006; Pass et al., 1995)

The added value that a brand name gives to a product is now commonly referred to as "brand equity" (Aaker, 1991). Brand name adds value to each of these interested parties which include the investors, manufacturers, and the retailers. Brand equity provides a strong platform for introducing new products and insulates the brand against competitive attacks. From the perspective of the trade, brand equity contributes to the overall image of the retail outlet. It builds store traffic, ensures consistent volume, and reduces risk in allocating shelf space (Cobb-Walgren et al., 1995). However, if the brand has no meaning to the consumer, automatically there wouldn't be of any value to the investors, the manufacturer, and the retailer unless there is value to consumer (Farquhar, 1989; Crimmins, 1992). 


\section{The Research Model}

\section{(Note 1)}

\subsection{Theory of Cognitive-Affective-Conative-Behavior}

Pursuing the emergence of research on behavioral perspective in customer loyalty which started in the 1970s, most researchers measured loyalty as a pattern of repeat purchase. The most relatable models for measurement of customer loyalty are Oliver's four-stage loyalty purchasing model (Oliver, 1997; Sawmong et al., 2004, p. 505).

Oliver's (1997, p. 392) framework model is derived from cognitive-affect-conation pattern model and he suggested that consumers can become loyal at each stage of the aforesaid model (cognitive loyalty-affective loyalty-conative loyalty-action loyalty).

Evidently, as noted by Oliver (1997), the state of action loyalty has not been examined in the literature so far. Most research only concentrates on the non-action "cognitive-affective-conative" underpinnings of loyalty. Reason being, action loyalty is not easy to observe as well as to measure even though it is ideal to be measured. Because of such difficulty, many researchers operationalized only at the conative stage or the behavioral intention measure. Thus, the concept of Oliver's four-stage loyalty purchasing model will be adopted whereby the conative loyalty approach will be used as the basis to develop the study conceptual model.

\subsection{Customer Loyalty and its Conceptualization}

There is identification of a need for greater knowledge and understanding in relation to customer loyalty (Knox \& Walker, 2001). This results from ambiguity that subsists over the meaning and measurement of the construct and the absence of academic literature in this area (Hart et al., 1999). Most analyses of loyalty have been from a behavioral perspective, excluding attitudinal type data and focussed on a deterministic perspective using stochastic models (Ehrenberg \& Goodhardt, 2000: McMullan, 2005). A problem linked with this type of analysis is that loyalty is about much more than just repeat purchase; someone who continues buying may be doing so out of inertia, indifference or exit barriers rather than loyalty (Reichheld, 2003). Latest studies have focus on the relationship between customer loyalty and quality, satisfaction (Martensen et al., 2000; McDougall \& Levesque, 2000) probability (Hallowell, 1996) or lack of profitability (Reinartz \& Kumar, 2000) and frequency programmed effectiveness (Shoemaker \& Lewis, 1999). Thus, despite all the attention in the general concept and the universal confidence in the benefits of loyalty, development in measuring and clearly defining it have been very limited (Knox \& Walker, 2001).

\subsection{Brand Equity and its Conceptualization}

In an increasingly competitive marketplace, branding makes Mazola more than just a cooking oil and Toyota more than just a car. In a market as changeable and competitive as a hotel industry, brand-awareness and customer loyalty among consumers is vital to keep marketers strategies up-to-date. Little has been written about the influence of advertising on Brand equity in an effort to gain customer loyalty in the independent hotel business. Since the term "brand equity" emerged in the 1980s, there has been a burgeoning interest in the subject among marketing academicians and practitioners. Cobb-Walgren et al., (1995) in their article states that, a 1991 survey of Marketing Science Institute members ranked brand equity the number one issue facing marketing management (Aaker 1991). Researchers have focused primarily on defining and measuring the concept and, to a lesser extent, understanding its causes and effects. There is a broad-based agreement that one of the major contributors to brand equity is advertising (Aaker and Biel 1993). According to Prentice (1991) and Ryan (1991, p. 19):

The consumer's perception of brand value comes from many sources, but essentially it is based on ideas rational or emotional - that set the brand apart from competitive brands. What kind of marketing activities implant these ideas about a brand's uniqueness in the mind? ....Advertising is the most common.

Farquhar (1989) also suggests that advertising can make positive brand evaluations and attitudes readily accessible in memory and it is crucial to the development of brand equity. This idea is supported by Herr and Fazio (1992), where they found that favorable brand attitudes will only guide perceptions and behavior if those attitudes can be instantly evoked.

To a layman, the terms "product" and "brand" are often used interchangeably. But a marketer and marketing experts know the difference. Farquhar $(1989$, p.24) and Cobb-Walgren $(1995$, p.25) states that a product is "something that offers a functional benefit". A brand, on the other hand, is "a name, symbol, design, or mark that enhances the value of a product beyond its functional value". Aaker (1991) further explain that the added value that a brand name gives to a product is now commonly referred to as "brand equity". 
A better understanding of brand equity depends on credible measures of the construct (Faircloth et al., 2001, p.62, 63). Many authors have presented several measures of brand equity (e.g.,Farquhar \& Ijiri, 1991; Kamakura \& Russess, 1993; Kapferer \& Laurent, 1988; Park \& Srinivasan, 1994; Simon \& Sullivan, 1993), after reviewing the above articles we conclude that the premium prices enjoyed by many brands have often been identified with brand equity (Aaker, 1991; Farquhar, 1989). Holden (1992) maintains that brand equity arises from greater brand choice probability by consumers and is reflected in willingness to pay premium prices. Other behavioral/choice variables that might indicate brand equity are likelihood of purchase (Smith \& Swinyard, 1983) and purchase intentions (Machleit, Madden, \& Allen, 1990). What is clear from the preceding and following discussions is that brand equity is a multidimensional construct and any measurement attempts must recognize its different dimensions.

Aaker $(1991,1996)$ indicates that the multidimensional concept in brand equity would consist of brand loyalty, brand awareness, perceived quality, brand associations, and other proprietary brand assets. Aaker (1991, p.120) further defined brand equity as:

... a set of brand assets and liabilities linked to a brand, its name and symbol that add to or subtract from the value provided by a product or service to a firm and/or to that firm's customers.

Similar dimensions were also identified by other researchers, whereby Shocker and Weitz (1988) propose brand loyalty and brand associations as the dimension for brand equity, and Keller (1993) suggests brand knowledge, comprising brand awareness and brand image as a component of brand equity. Taking into considerations of the suggestions mentioned above, we identify perceived quality, brand loyalty, and brand awareness with strong brand associations as common dimensions of brand equity. Indeed, brand names add value to different prospect, which include the investors, the manufacturer, the retailer, or the consumer (Cobb-Walgren, 1995). But a brand will only be of value to the investors, the manufacturer, and the retailer only if there is value to the consumer (Cobb-Walgren, 1995; Crimmins , 1992; Farquhar, 1989).To further support the above views, Keller (1998, p.45) argues that a brand possesses positive customer-based brand equity when customers react more favorably to a (brand identified) product. Keller (1988) defines brand equity as:

...the differential effect that brand knowledge has on consumer response to the marketing of that brand.

Taylor et al., (2004) indicates that brand equity is unique from customer loyalty .Brands do possess negative customer-based brand equity, through customers' expression when consumers react less favorably to the marketing activities associated with a brand (Keller, 1988; Taylor et al., 2004). In Keller's view, one of the characteristics of brands possessing strong brand equity is stronger brand loyalty. This view correspond with that of Aaker (1991) who argued that brand loyalty could be considered both as a dimension and an outcome of brand equity.

\subsection{Concept of Advertising}

In a study conducted by Cobb-Walgren et al., (1995) they found that advertising can influence brand equity a number of ways. With advertising, it is able to create awareness of the brand and increase the probability that the brand is included in the consumer's evoked set. It can contribute to brand associations which, when stored in accessible memory, translate into "non-conscious but reliable behavioral predisposition" (Krishnan \& Chakravarti, 1993, p. 214). Advertising can affect the perceived quality of a brand, and it can influence usage experience (Cobb-Walgren et al., 1995).

Nelson (1974) demonstrated that heavy advertising can improve perceived quality for experience goods, which by definition are difficult to evaluate prior to purchase. Advertising can make positive brand evaluations and attitudes readily accessible in memory (Cobb-Walgren et al., 1995, p. 28; Farquhar, 1989). This is crucial to the development of brand equity, where Herr and Fazio (1992) found in their study that favorable brand attitudes will shape the perceptions and behavior of a consumer if those attitudes can be instantly enhance. These perceptions, in turn, contribute to the meaning or value that the brand adds to the consumer - i.e., brand equity (Cobb-Walgren et al., 1995). Brand equity will then influences consumer preferences and purchase intentions, and ultimately brand choice.

\subsection{The Mediating Role of Advertising}

It is quite common to regard advertising as a major factor in leveraging brand equity (Achenbaum, 1989; Lindsay, 1990). It is worth noting that consumers are not passive recipients of image-laden advertising. Joyce (1991) suggests that "people took away from communications, including advertising, what they chose to, and indeed brought existing preconceptions to them" (p. 269). In reality, brand values are subjective, a point stressed by McDonald (1992) who suggests that "it is consumers and their habit-forming tendencies that create branding; 
branding is inseparable from the ability to choose. What advertising does is to help control the acquisition of value, and give it direction" (p. 114).

Advertising can influence brand equity a number of ways. It can create awareness of the brand and increase the probability that the brand is included in the consumer's evoked set. It can contribute to brand associations which, when stored in accessible memory, translate into "non-conscious but reliable behavioral predispositions" (Krishnan \& Chakravarti, 1993, p. 214). Advertising can affect the perceived quality of a brand, and it can influence usage experience. No published studies to date have examined all of the components of brand equity as they relate to advertising. Johnson (1984) looked at the relationship between advertising spending and brand loyalty. For those brands that suffered a decline in brand loyalty over time, one of the major contributing factors was a lack of advertising support.

Therefore it is very important for company's brand to develop a well-communicated strategy that would help them gain a better brand's position and protecting them from other rivals or competitors. Thus, this paper proposed the role of advertising as the moderator on the relationship between brand equity dimension and customer loyalty in Langkawi (SMEs) independent hoteliers context.

On the basis of the above literature, we propose that:-

H1: There is a positive relationship between brand equity and customer loyalty.

H2: There is a positive relationship between brand equity and advertising appeal.

H3: There is a positive relationship between advertising appeal and customer loyalty.

H4: Advertising mediates the relationship between brand equity and customer loyalty.

\section{Suggestions for Future Research}

A related issue concerning the content of advertising whereby the nature and quality of advertising content play a role in the perceptual components of brand equity and may influence behavioral manifestations. Other variables besides advertising could also account for the differences in brand equity scores. Sales promotion tools such as coupons and price discounts should also be taken into considerations as it was also previously found to have an impact on advertising. Recent trend in advertising, where high financial and functional rise company in Malaysia have been using advertising as a medium to fulfill their social responsibility, thus indirectly enhance their brand equity among the general public

The entrepreneur plays a key role in the SME and exerts considerable influence on the structure and culture of a company. The value of this study lies in the fact that it places the role of brand management firmly in an SME context. Future research should also look into the influence of the entrepreneur, not just as the personification of the brand, but also as the individual who shapes the company structure. In addition, a study of the success of an SME, in the light of the role that brand management played within it, might well offer increased insight into the problems faced by all SMEs in managing brand.

\section{References}

Aaker, D.A. (1991). Managing Brand Equity: Capitalizing on the Value of a Brand Name. The Free Press, New York. NY.

Aaker, D.A. (1996). Measuring Brand Equity Across Products and Markets. California Management Review, 38 (Spring), 102-120.

Aaker, D.A., \& Biel, A.L. (1993). Brand Equity and Advertising. Hillsdale, NJ: Lawrence Erlbaum Associates. Achenbaum, A. (1989). How to breathe new life into brands. Advertising Age, 60(18), 24-70.

Bank Negara Malaysia. (2005). Secretariat to National SME Development Council. Definitions for Small and Medium Enterprises in Malaysia (Approved for Adoption by National SME Development Council on 9 June 2005).

Beaver, G., \& Prince, C. (2004). Management, strategy and policy in the UK small business sector: a critical review. Journal of Small Business and Enterprise Development, 11(1), 34-49.

Belch, G.E., \& Belch, M.A. (2001). Advertising and Promotion; An integrated marketing communications perspective ( $5^{\text {th }}$ ed.). McGraw Hill Irwin.

Buhalis, D., \& Main, H. (1997). Catalysts in introducing information technology in small and medium sized hospitality organizations. Min Tjoa, A. (eds). Information and Communication Technologies in Tourism 1997. 
Cobb-Walgren, C.J., Ruble, C.A., \& Donthu, N. (1995). Brand Equity, Brand Preference, and Purchase Intent. Journal of Advertising, XXIV(3), 25-40.

Cohen, W.A., \& Stretch, S.M. (1989). Problems in Small business marketing as perceived by owners. Proceedings of Research Symposium on the Marketing/Entrepreneurship Interface, Chicago, IL, 429-32.

Crimmins, J.C. (1992). Better Measurement and Management of Brand Value. Journal of Advertising Research, 32(July/August), 11-19.

Dass, M.J. (2005). Rebranding Malaysia. Welcome to Sun2Surf. [Online] Available: http://www.sun2surf.com.

Davis, S.M. (2000). Brand Asset Management: Driving Profitable Growth through Your Brands. Jossey-Bass, San Francisco.

Ehrenberg A.S.C., \& Goodhardt, G. (2000). New brands: Near instant loyalty. Journal of Marketing Management, 16 (6), 607-617.

Faircloth, J.B., Capella, L.M., \& Alfoord, B.L. (2001). The Effect of Brand Attitude and Brand Image on Brand Equity. Journal of Marketing_Theory and Practice, Summer, 61-75.

Farquhar, P., \& Yuri, I. (1991). Momentum Accounting for Brand Equity. In Managing Brand Equity: Conference Summary. Eliot Maltz, ed., Marketing Science Report, 91 (110), 12-13.

Farquhar, P.H. (1989). Managing Brand Equity. Marketing Research,1(September), 24-33.

Goodchild, J., \& Callow, C. (2001). Brands: Visions \& Values. John Wiley \& Sons, New York, NY.

Hallowell, R. (1996). The relationship of customer satisfaction, customer loyalty, and profitability: An empirical study. International Journal of Service Industry Management, 7(4), 27-42.

Hart, S., Smith, A., Sparks, L., \& Tzokas, N. (1999). Are loyalty schemes a manifestation of relationship marketing? Journal of Marketing Management, 15(6), 541-562.

Herr, P.M., \& Fazio, R.H. (1992). The Attitude-to-Behavior Process: Implications for Consumer Behavior. Advertising Exposure, Memory, and Choice, Andrew A. Mitchell, ed., Hillsdale, NJ: Lawrence Erlbaum Associates.

Hill, J. (2001). A multidimensional study of the key determinants of effective SME marketing activity: part 1. International Journal of Entrepreneurial Behaviorsa \& Research, 7 (5), 171-204.

Holden \& Stephen, J.S. (1992). Brand Equity Through Brand Awareness: Measuring and Managing Brand Retrieval, Ph.D. Dissertation, University of Florida.

Holverson, S., \& Revaz, F. (2006). Perceptions of European independent hoteliers: hard and soft branding choices. International Journal of Contemporary Hospitality Management, 18(5), 398-413.

Huang, X., \& Brown, A. (1999). An analysis and classification of problems in small business. International Small Business Journal, 18(1), 73-85.

Jacoby, J., \& Chestnut, R. (1978). Brand loyalty: Measurement and Management. John Wiley and Sons, New York, NY.

Johar, J.S., \& Sirgy, M.J. (1991). Value-expressive versus utilitarian advertising appeals: when and why to use which appeal. Journal of Advertising, 20 (3), 23-33.

Johnson, T. (1984). The Myth of Declining Brand Loyalty. Journal of Advertising Research, 24 (February/March), 9-17.

Joyce, T. (1991). Models of the advertising process. How Advertising Works and How Promotions Works. ESOMAR, Amsterdam, ESOMAR conference proceedings, 22(24), 267-281.

Kamakura, W.A., \& Gary, J.R. (1993). Measuring Brand Value with Scanner Data. International Journal of Research in Marketing, (10), 9-22.

Kapferer, J.N., \& Giles, L. (1988). Consumer Brand Sensitivity: A Key to Measuring and Managing Brand Equity. Marketing Science Institute Report, 88(104), 20-22.

Keller, K.L. (1993). Conceptualizing, Measuring, and Managing Customer-Based Brand Equity. Journal of Marketing, 57 (1), 1-22.

Keller, K.L. (1998). Strategic Brand Management: Building, Measuring, and Managing Brand Equity. Prentice Hall. Upper Saddle River. NJ. 
Knox, S., \& Walker, D. (2001). Measuring and managing brand loyalty. Journal of Strategic Marketing, 9 (2), $111-128$.

Kraft, F.B., \& Goodell, P.W. (1989). Identifying the Health Conscious Consumer. Sage, Newbury Park, CA.

Krake, F.B.G.J.M. (2005). Successful brand management in SMEs: a new theory and practical hints. Journal of Product \& Brand Manament, 14(4), 228-238.

Krishnan, H.S., \& Chakravarti, D. (1993). Varieties of Brand Memory Induced by Advertising: Determinants, Measures, and Relationships. In Brand Equity and Advertising, David A. Aaker and Alexander L. Biel, eds., Hillsdale, NJ: Lawrence Erlbaum Associates.

Lindsay, M. (1990). Establish brand equity through advertising. Marketing News, 24(2), 16.

Machleit, K.A., Thomas, J.M., \& Chris, T.A. (1990). Measuring and Modeling Brand Interest as an Alternative Effect with Familiar Brands. Advances in Consumer Research, 17, 223-230.

Main, H. (2001). The use of the internet by hotels in Wales - a longitudinal study: 1994-2000. International Journal of Hospitality Information Technology, 2(2), 35-44.

Malaysian Ministry of Finance. (2005). Malaysian Economic Report, KL: Malaysia. Management. 17(1), 99-120.

Martensen, A., Gronholdt, L., \& Kristensen, K. (2000). The drivers of customer satisfaction and loyalty: Cross-industry findings from Denmark. Total Quality Management, 11, 4/6, 544-553.

McDonald, C., \& De Chernatony, L. (1989). Branding termi9nology - the real debate. Marketing Intelligence \& Planning, 7(7/8), 29-32.

McDougall, G.H.G., \& Levesque, T. (2000). Customer satisfaction with services: Putting perceived value into the equation. Journal of Services Marketing, 14(5), 392-410.

McMullan, R. (2005). A multiple-item scale for measuring customer loyalty development. Journal of Services Marketing, 19(7), 470-481.

Meenaghan, T. (1995). The role of advertising in brand image development. Journal of Product \& Brand Management, 4(4), 23-34.

Moriarity, S.E. (1991). Creative Advertising: Theory and Practice (2 ${ }^{\text {nd }}$ ed.). Englewood Cliffs, NJ: Prentice Hall, 76.

Morrison, A. (1998). Small firm co-operative marketing in a peripheral tourism region. International Journal of Contemporary Hospitality Management, 10(5). 191-197.

Nelson, P. (1974). Advertising as Information. Journal of Political Economy, 82(July/August), 729-754.

Park, C.S., \& Srinivasan, V. (1994). A Survey-Based Method for Measuring and Understanding Brand Equity and Its Extendibility. Journal of Marketing Research, 31(5), 271-288.

Park, C.W., Jaworski, B.J., \& Maclnnis, D.J. (1986). Strategic brand concept-image management. Journal of Marketing, 50, 135-145.

Pass, C., Lowes, B., Pendleton, A., \& Chadwick, L. (1995). Collins Dictionary of Business, $2^{\text {nd }}$ ed. HarperCollins Publishers, Glasgow.

Prentice, R.M. (1991). A Breakthrough That Reveals Why Most Promotions Cost 7 times as Much as Advertising. As cited in, It Works! How Investment Spending in Advertising Pays Off, Bernard Ryan, New York: American Association of Advertising Agencies, 1991.

Priester, J.R., \& Petty, R.E. (2003). The influence of spokesperson trustworthiness on message elaboration, attitude strength, and advertising effectiveness. Journal of consumer psychology, 13(4), 408-421.

Reichheld, F. (2003). The one number you need to grow. Harvard Business Review, 82(6), 46-54.

Reinartz, W.J., \& Kumar, V. (2000). On the profitability of long-life customers in a noncontractual setting: An empirical investigation and implications for marketing. Journal of Marketing, 64(4), 17-35.

Ryan, B. (1991). It Works! How Investment Spending in Advertising Pays Off. New York: American Association of Advertising Agencies, 1991.

Shocker, A.D. (1993). New Books in Review-Managing Brand Equity. Journal of Marketing Research, 30(5), 256-258. 
Shocker, A.D., \& Barton, W. (1988). A Perspective on Brand Equity Principles and Issues. In Defining, Measuring, and Managing Brand Equity. Report No. 88-104. Ed. Lance Leuthesser. Cambridge, MA: Marketing Science Institute, 2-4.

Shoemaker, S., \& Lewis, R.C. (1999). Customer loyalty: The future of hospitality marketing. International Journal of Hospitality Management, 18(4), 345-370.

Simon, C.J., \& Sullivan, M.W. (1993). The Measurement and Determinants of Brand Equity: A Financial Approach. Marketing Science, 12, 1(winter), 28-52.

Smith, R.E., \& William, R.S. (1983). Attitude-Behavior Consistency: The Impact of Product Trial Versus Advertising. Journal of Marketing Research, 20(8), 257-267.

Storey, D.J. (1994). Understanding the Small Business Sector. Routledge, New York, NY.

Taylor, S.A., Celuch, H., \& Goodwin, S. (2004). The importance of brnad equity to customer loyalty. Journal of Product \& Brand Management, 13(4), 217-227.

Yoo, B., Donthu, N., \& Lee, S. (2000). An Examination of Selected Marketing Mix Elements and Brand Equity. Journal of the Academy of Marketing Science, 28(2), 195-211.

Note

Note 1. Figure 1 the proposed research model.

Brand equity

- Brand Loyalty

- Perceived Quality/Leadership

- Brand Associates/Differentiation

- Brand Awareness

(Aaker, 1996)

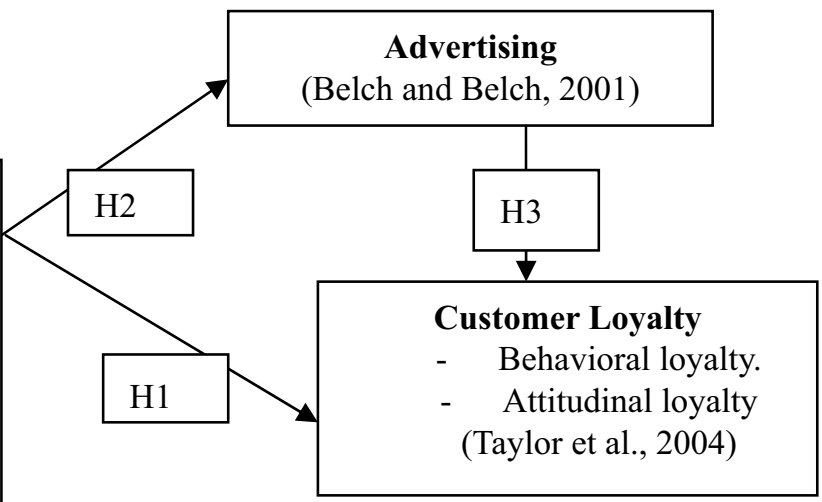

Figure 1. The proposed research model 